\section{Production Techniques for Strawberry Plugs in West-central Florida}

\author{
Emmanuel A. Torres-Quezada ${ }^{1}$, Lincoln Zotarelli ${ }^{1}$, \\ Vance M. Whitaker ${ }^{1,2}$, Rebecca L. Darnell ${ }^{1}$, Kelly Morgan ${ }^{4}$, \\ and Bielinski M. Santos ${ }^{3}$
}

ADDITIONAL INDEX WORDs. early yield, Fragaria $\times$ ananassa, strawberry cultivars, strawberry transplants, time in nursery, tray size, water conservation

SUMMARY. Florida-produced strawberry (Fragaria $\times$ ananassa) plug transplants (SP) are a potential alternative to bare-root transplants (BR). The adoption of this technology could represent a reduction in water usage for plant establishment and potentially higher early yield, as SP may establish more quickly than BR. Thus, the objective of this study was to evaluate the effect of time in nursery and tray sizes, on early and total strawberry yield for Florida-produced SP for 'Florida Radiance', 'Strawberry Festival', and Sweet Sensation ${ }^{\circledR}$ 'Florida127'. Runners from Floridaproduced mother plants were collected in mid and late August from 2012 to 2015. SP were grown for either 4 or 6 weeks according to the treatment and established in 30-, 40-, 50-, and 72-cell trays, and compared with BR (control). Additionally, strawberry tips from California were evaluated for SP production. BR consistently had higher early yield than SP, ranging from 36\% to $91 \%$, between 2012 and 2016 . SP produced the same or higher total yield than BR. Florida-produced SP should be grown for 4 weeks before field transplanting in 50-cell trays based on the results of this study. Furthermore, there was no difference between California and Florida tips for total yield. In all seasons, all SP were established with $20 \%$ of the total irrigation water used for the BR. Thus, SP could potentially result in water savings of almost $820,800 \mathrm{gal} /$ acre per season, but the early yield of SP would need to be improved to match $\mathrm{BR}$ performance.

$\mathrm{F}$ lorida is the second-largest strawberry (Fragaria $\times$ ananassa) producer in the United States. The industry in Florida generally relies on short-day cultivars, planted in early October, and harvested in late November. Strawberry transplants for the winter season are usually grown in northern latitudes and shipped to southern states in late

Received for publication 28 Oct. 2019. Accepted for publication 4 Feb. 2020

Published online 5 March 2020.

${ }^{1}$ Horticultural Sciences Department, Institute of Food and Agricultural Sciences (IFAS), University of Florida, Gainesville, FL 32611

${ }^{2}$ Gulf Coast Research and Education Center, Institute of Food and Agricultural Sciences, University of Florida, 14625 CR 672, Wimauma, FL 33598

${ }^{3}$ Horticultural Sciences Department, Institute of Food and Agricultural Sciences, University of Florida, Gainesville, FL 32611

${ }^{4}$ Southwest Florida Research and Education Center, Institute of Food and Agricultural Sciences, University of Florida, 2685 State Road 29 North, Immokalee, FL 34142

B.M.S. is a former Associate Professor.

L.Z. is the corresponding author. E-mail: lzota@ufl. edu.

This is an open access article distributed under the CC BY-NC-ND license (https://creativecommons.org/ licenses/by-nc-nd/4.0/).

https://doi.org/10.21273/HORTTECH04529-19
September for planting (Hochmuth 2004). The most common strawberry transplant in Florida is bareroot (BR) with leaves still attached (Santos et al., 2012). Under the traditional production practices of Florida, BR require between 3500 and $5500 \mathrm{~m}^{3} \cdot \mathrm{ha}^{-1}$ per season of continuous sprinkler irrigation during daylight hours to reduce air temperature around the strawberry crown (Bish et al., 1997; Cluever et al., et al., 2006a; Hokanson et al.,
2016; Forcelini et al., 2017; Santos et al., 2012). Additionally, the BR field-harvesting process reduces the number of functional leaves, creates entry points for pathogen infection, and increases variability in transplant size and flowering pattern (Bish et al., 1997; Hokanson et al., 2004).

Strawberry plug transplants (SP) are an alternative to BR. The active root system and water retention capacity of the SP allows them to establish with minimal sprinkler irrigation (Crawford et al., 2000; Durner et al., 2002; Janisch et al., 2012). In addition to the potential water savings, SP exposed to adequate flower induction conditions in the nursery can produce higher early and total yield than BR (Durner, 2015; Hennion et al., 1997; Lieten, 2012; Treder et al., 2015; Wan et al., 2018).

One limitation of SP is their higher cost $(\$ 0.37-\$ 0.38$ per transplant), compared with BR ( $\$ 0.15-$ $\$ 0.16$ per transplant), which could increase total production costs in Florida by $\$ 3833 /$ acre, assuming a plant density of 17,424 plants/acre (Lareault Inc., unpublished). An alternative to reduce the acquisition cost of SP is the optimization of Florida-produced SP, allowing a reduction of shipping and handling cost of plant material for Florida strawberry growers. Despite the potential benefits of SP transplants, there are still several challenges to overcome for the adoption of Florida-produced SP.

Several studies have evaluated the performance of out-of-state conditioned SP in comparison with BR in Florida (Bish et al., 1997, 2003; Cantliffe et al., 2007; Hochmuth

\begin{tabular}{llll}
\hline $\begin{array}{l}\text { Units } \\
\text { To convert U.S. to } \\
\text { SI, multiply by }\end{array}$ & U.S. unit & SI unit & $\begin{array}{l}\text { To convert SI to } \\
\text { U.S., multiply by }\end{array}$ \\
\hline 0.4047 & $\mathrm{acre}(\mathrm{s})$ & $\mathrm{ha}$ & 2.4711 \\
29.5735 & $\mathrm{fl} \mathrm{oz}$ & $\mathrm{mL}$ & 0.0338 \\
0.3048 & $\mathrm{ft}$ & $\mathrm{m}$ & 3.2808 \\
0.0929 & $\mathrm{ft}^{2}$ & $\mathrm{~m}^{2}$ & 10.7639 \\
0.0700 & $\mathrm{ft}^{3} / \mathrm{acre}$ & $\mathrm{m}^{3} \cdot \mathrm{ha}^{-1}$ & 14.2913 \\
3.7854 & $\mathrm{gal}$ & $\mathrm{L}$ & 0.2642 \\
9.3540 & $\mathrm{gal} / \mathrm{acre}$ & $\mathrm{L} \cdot \mathrm{ha}^{-1}$ & 0.1069 \\
2.54 & inch $(\mathrm{es})$ & $\mathrm{cm}$ & 0.3937 \\
25.4 & inch $(\mathrm{es})$ & $\mathrm{mm}$ & 0.0394 \\
16.3871 & inch & $\mathrm{cm}$ & 0.0610 \\
1.1209 & lb/acre & $\mathrm{kg} \cdot \mathrm{ha}^{3}$ & 0.8922 \\
0.0254 & $\mathrm{mil}(\mathrm{s})$ & $\mathrm{mm}$ & 39.3701 \\
28.3495 & $\mathrm{Oz}$ & $\mathrm{g}$ & 0.0353 \\
28,350 & $\mathrm{oz}$ & $\mathrm{mg}$ & $3.5274 \times 10^{-5}$ \\
2.2417 & ton $(\mathrm{s}) / \mathrm{acre}$ & $\mathrm{Mg}^{3} \cdot \mathrm{ha}^{-1}$ & 0.4461 \\
$\left({ }^{\circ} \mathrm{F}-32\right) \div 1.8$ & $\mathrm{o} F$ & ${ }^{\circ} \mathrm{C}$ & $\left({ }^{\circ} \mathrm{C} \times 1.8\right)+32$
\end{tabular}


et al., 2006a, 2006b; Southwest Florida Water Management District, 2000). However, few researchers have evaluated the response of unconditioned Florida-produced SP to time in nursery before field transplanting. Across the United States, recommendations for time in nursery before transplanting range from 4 to 7 weeks for SP (Crawford et al., 2000; Takeda et al., 2010). The optimization of production techniques for unconditioned SP is necessary to exploit the potential of Florida-produced SP. Overgrown SP could become rootbound. Conversely, undergrown SP could have reduced early yield.

Similarly, SP are directly rooted into specially designed trays, usually containing peat-based media (Durner et al., 2002). Trays are typically classified by their cell number, varying in the quantity of growing media that can be contained in each cell. Larger cells could allow for a higher volume of growing media and greater root growth but would increase the amount of space needed for SP production, reducing profitability, and could also increase the time for an adequate formed root ball. Conversely, smaller cells could restrain root growth and reduce SP early and total yield.

The primary objectives of this study were to evaluate the effect of time in nursery and tray size on early and total yield for Florida-produced $\mathrm{SP}$, and to compare their performance to $\mathrm{BR}$.

\section{Materials and methods Expt. 1: Evaluation of time in nursery}

Four field studies were conducted in consecutive seasons between 2012 and 2016 at the Gulf Coast Research and Education Center of the University of Florida, located in Wimauma, FL (lat. $27^{\circ} 75^{\prime} \mathrm{N}$, long. $82^{\circ} 22^{\prime} \mathrm{E}$ ).

Nursery. Strawberry mother plants were planted in April of each year in 1-gal pots using potting mix (Farfard-2; Farfard, Agawam, MA) as growing media in a $1800-\mathrm{ft}^{2}$ greenhouse (United Greenhouse Systems, Edgerton, WI). Drip emitters (John Deere, San Diego, CA) with a flow of $\approx 4 \mathrm{fl} \mathrm{oz} / \mathrm{min}$, were used for irrigation of the mother plants. Irrigation schedule delivered $12.8 \mathrm{fl} \mathrm{oz} /$ plant per cycle, three to four times per day.
Mother plants received $26 \mathrm{mg} / \mathrm{pot}$ (1 lb/acre) of nitrogen $(\mathrm{N})$ per day, assuming a plant density of 17,424 plants/acre, with a solution of $5 \mathrm{~N}$ 0.9P-6.6K (Dyna Flo 5-2-8 YZ; Chemical Dynamics, Plant City, FL), containing nutrient levels of $1.4 \%$ calcium (Ca), $0.4 \%$ magnesium (Mg), $0.02 \%$ boron (B), $0.03 \%$ manganese $(\mathrm{Mn})$, and $0.02 \%$ zinc $(\mathrm{Zn})$.

Runners with two to three expanded leaves were collected from the mother plants and transplanted into 50 -cell trays $\left(75 \mathrm{~cm}^{3}\right.$ per cell $)$, using the same growing media as described above. Slow-release fertilizer containing 14N-6P-11.6K (Osmocote Plus Multipurpose Plant Food; Scotts, Marysville, $\mathrm{OH}$ ) was incorporated to the trays' growing media at a rate of $50 \mathrm{~g}$ of $\mathrm{N}$ per tray, before planting. During the nursery stage, SP were irrigated for $8 \mathrm{~h} \cdot \mathrm{d}^{-1}$ for the first 7 $\mathrm{d}$ after transplanting, using microsprinkler (Netafim, Hanegev, Israel) with a flow rate of $\approx 0.25 \mathrm{gal} / \mathrm{min}$. Each microsprinkler irrigated $\approx 12$ trays. Starting on the $8 \mathrm{~d}$, SP were irrigated $30 \mathrm{~min} \cdot \mathrm{d}^{-1}$.

Fruit FIELD. The soil at the experimental site is classified as a Myakka fine sand (siliceous hyperthermic Oxyaquic Alorthod) with $<1.5 \%$ soil organic matter (U.S. Department of Agriculture, 2019). For all seasons, the soil was tilled twice to a depth of 8 inches, before planting (BP421 double disk; Kenco Manufacturing, Atoka, OK). In late August, raised pressed beds were formed with a strawberry bedder with dimensions of 27 inches width at the base, 24 inches width at the top, and 10 inches high. Beds were spaced $4 \mathrm{ft}$ apart on center. During pressing, beds were fumigated with 1,3 dichloropropene $(63.4 \%)+$ chloropicrin $(34.7 \%)$ at a rate of $300 \mathrm{lb} / \mathrm{acre}$ (Telone C-35; Dow AgroScience, Indianapolis, IN). Immediately after fumigation, beds were covered with high-density black polyethylene mulch film (1 mil thick; Intergro Co., Clearwater, FL). At the same time, one drip tape line $(0.13 \mathrm{gal} / \mathrm{min}$ per emitter, 12 inches between emitters; Rivulis, Gvat, Israel) was placed on the top center of the bed, directly under the polyethylene film. Planting holes were punched on top of the bed with a strawberry bed hole puncher with floating wheel frames. Strawberry transplants were planted by hand.
The experimental area was set with $4.5 \mathrm{gal} / \mathrm{min}$ sprinkler heads, spaced at $48 \times 48 \mathrm{ft}$. After transplanting, sprinkler irrigation was applied for $8 \mathrm{~h} \cdot \mathrm{d}^{-1}$ for the first $2 \mathrm{~d}$ for all the experimental units. After the first $2 \mathrm{~d}$, establishment water was suspended for SP and sprinkler irrigation was substituted with microsprinkler irrigation $(0.25 \mathrm{gal} / \mathrm{min})$. Irrigation for establishment continued for the BR for $8 \mathrm{~h} \cdot \mathrm{d}^{-1}$ for another $8 \mathrm{~d}$. Total water applied for BR establishment was $495,916 \mathrm{gal} / \mathrm{acre}$, while SP received $82,080 \mathrm{gal} /$ acre.

Fertilizer was applied according to the strawberry guidelines for the state of Florida (Simonne and Dukes, 2009). Daily fertilizer applications started I week after transplanting (WAT) through the drip lines using a hydraulic injector (Dosatron, Clearwater, FL) to pump concentrated stock solution of $5 \mathrm{~N}-0.9 \mathrm{P}-6.6 \mathrm{~K}$ (Dyna Flo 5-2-8 YZ; Chemical Dynamics, Plant City, FL) into the irrigation water, using a dilution rate of 1:50 (by volume). Irrigation volume was equivalent to the average reference evapotranspiration for westcentral Florida from October to March (Simonne and Dukes, 2009), and it was split equally into two daily irrigation cycles, starting at 0800 and 1300 HR, respectively. Runners were pruned $\approx 10$ WAT. All evaluated cultivars are classified as short-day plants.

2012-13 SEASON. Runners for SP production were collected 15 and 30 Aug. 2012, and SP were grown for either 4 or 6 weeks according to the treatment. Five treatments were tested: BR [control (Crown Nursery, Red Bluff, CA)], 4- and 6-week-old SP Florida-grown transplants, and 4and 6-week-old SP Florida-grown transplants with indole-3-butyric acid [IBA $(0.10 \%$ by weight $)]$ applied to the roots.

On 1 Oct. 2012, 'Strawberry Festival' BR and SP with three to five leaves were established in a randomized complete block design with four replications. Transplants were planted in double row, 15 inches apart. Experimental units were approximately $12.5 \mathrm{ft}$ long with 20 plants. Plots were harvested twice per week starting 9 weeks after transplanting (WAT) on 10 Dec. 2012 and until 18 WAT on 15 Feb. 2013. Early marketable yield was defined as the cumulative marketable weight of all harvest until 15 
Dec. 2012. Total marketable yield consisted of the cumulative weight of all 20 harvests until 15 Feb. 2013. Marketable yield was defined as strawberry fruit with fresh weight of $10 \mathrm{~g}$ or above, without visible blemishes, and at least $75 \%$ external red color. Average fruit weight was determined by dividing the total marketable yield of each treatment by its corresponding fruit number.

2013-14 SEASON. 'Strawberry Festival' and 'Florida Radiance' runners for SP production were harvested on 2 and 16 Sept. 2013. Two factors were evaluated: transplant type and cultivar. Transplant type consisted of BR control and 4- and 6-week-old SP.

During the nursery stage, BR received $\approx 332 \mathrm{~h}$ of conditioning [air temperature between 46 and $60{ }^{\circ} \mathrm{F}$ (Lassen Canyon Nursery, 2016)]. Treatments were established in the field in 14 Oct. 2013 in a randomized complete block design with four replications. Experimental units were proximately $15 \mathrm{ft}$ long with 24 plants.

Plots were harvested twice per week between 9 Dec. 2013 (8 WAT) and 20 Feb. 2014 (19 WAT), with a total of 22 harvests. Early and total marketable yield and average fruit weight were determined as described above. Crown diameter and number were collected at 6,12 , and 18 WAT.

2014-15 AND 2015-16 SEAsons. 'Strawberry Festival', Sweet Sensation ${ }^{\circledR}$ 'Floridal27' (hereafter referred to as 'Florida127'), and 'Florida Radiance' runners were harvested and transplanted on 24 Aug. and 7 Sept. 2014. The transplant types tested were BR (control) and 4- and 6-week-old SP. During the nursery stage in 2014-15 and 201516 , BR received $\approx 238$ and $264 \mathrm{~h}$ of conditioning, respectively (Lassen Canyon Nursery, 2016). Treatments were arranged in a split-plot design with cultivars as the main plot and transplant type in the subplot with four replications. Each treatment plot was $20 \mathrm{ft}$ long, with 32 plants.

Treatments were transplanted in the field on 6 Oct. 2014 and 7 Oct. 2015. Plots were harvested twice per week between 4 Dec. 2014 (8 WAT) and 2 Mar. 2015 (17 WAT). The following season, transplants were first harvested 6 WAT on 19 Nov. 2015 with the season ending 19 WAT on 16 Feb. 2016. Early and total marketable yield and average fruit weight were determined as previously described. Shoot dry biomass was collected at 4 , $8,12,16$, and 20 WAT. Total dry biomass was determined by adding up shoot and runners' dry biomass.

Air temperature at $2 \mathrm{~m}$ height was collected every 15 min with a temperature sensor (CS215; Campbell Scientific, Logan, UT). Rainfall was collected with a tipping bucket $(\mathrm{H}$ 340; Campbell Scientific) for all four seasons, installed at the experimental site. Weather data were collected from the Florida Automated Weather Network web site (FAWN, 2019).

\section{Expt. 2: Evaluation of tray size}

Two field studies were conducted in consecutive seasons to evaluate the effect of SP tray size on strawberry yield. Mother plant establishment and field preparations were performed as described above.

2013-14 SEASON. 'Strawberry Festival' runners with two to three expanded leaves were harvested on 25 Aug. 2013, and planted into 30-, 40-, 50-, and 72-cell trays, using the same growing media as described previously. Strawberry BR were used for comparison as previously.

All trays outside dimension were 10.5 inches wide by 20.8 inches long by 2.25 inches high. The 30 -cell trays had a top cell diameter of 2.4 inches with a maximum dry volume of 10.5 inch $^{3}$ and a rose pot shape (Landmark Plastic, Akron, OH). The 40-cell trays had a top cell diameter of 1.96 inches with a maximum dry volume of 6.8 inch $^{3}$ and a square shape (Landmark Plastic). The 50-cell trays had a top cell diameter of 1.75 inches with a maximum dry volume of 5.4 inch $^{3}$ and a round, circular shape (Landmark Plastic). The 72-cell trays had a top cell diameter of 1.32 inches with a maximum dry volume of 2.97 inch $^{3}$ and a round, circular shape (Landmark Plastic). SP were grown for 6 weeks before transplanting, in both seasons.

Treatments were established in a randomized complete block design with four replications. Experimental units were $15 \mathrm{ft}$ long with 24 plants. Crown diameter and number were collected at 6,12 , and 18 WAT. Plots were harvested twice per week between 9 WAT on 9 Dec. 2013 and 19 WAT on 20 Feb. 2014.

2014-15 SEASON. 'Strawberry Festival' and 'Florida Radiance' runners were harvested on 24 Aug. 2014 and transplanted into 50- and 72cell trays. Additionally, CA-grown 'Strawberry Festival' and 'Florida Radiance' runners were shipped to Florida on 20 Aug. 2014 and established in the same tray sizes (Crown Nursery). Before establishment, the California runner tips received $\approx 10 \mathrm{~h}$ of conditioning (Lassen Canyon Nursery, 2016).

Treatments were arranged in a split-plot design with the cultivar as the main plot and the transplant type in the subplot. Experimental units were $20 \mathrm{ft}$ long, with 32 plants/plot. Crown diameter and number were collected at 4, 8, 12, 16, and 20 WAT. Plots were harvested twice per week between 9 WAT on 6 Dec. 2014 and 17 WAT on 3 Feb. 2015, with a total of 23 harvests.

\section{Statistical analysis}

EXPT. 1: Evaluation OF TIME IN NURSERY. In 2012-13 and 2013-14, treatments were analyzed using analysis of variance $(P \leq 0.05)$. In case of significant difference, treatment values were separated using Fisher's protected least significant difference test (Statistix version 9; Analytical Software, Tallahassee, FL).

In 2014-15 and 2015-16, data were analyzed using analysis of variance $(P \leq 0.05)$. Season, cultivars, and transplant type were analyzed for interaction and main factor effects. Due to significant interaction among season and treatments, analyses were performed separately for each season. Plant biomass was analyzed independently at each measured stage. In case of significance difference, treatment values were separated using Fisher's protected least significant difference test (Statistix version 9).

EXPT. 2: Evaluation OF tray SIZES. In the 2014-15, transplant type was analyzed for interaction with cultivar using analysis of variance $(P \leq$ $0.05)$. In case of significance differences among treatments, mean values were separated using Fisher's protected least significant difference test (Statistix version 9).

\section{Results \\ Expt. 1: Evaluation of time in nursery}

2012-13 SEASON. There were no differences in any plant growth parameters among 4- and 6-week-old 
SP with and without IBA and BR treatments. Crown diameter averaged $17.9 \mathrm{~mm}$ at 6 WAT $(P=0.671)$, $50.7 \mathrm{~mm}$ at 12 WAT $(P=0.291)$, and $69.7 \mathrm{~mm}$ at $18 \mathrm{WAT}(P=0.698)$. At 6 WAT, all treatments averaged one crown per plant, increasing to five crowns per plant at 18 WAT $(P=$ 0.295 ) (data not shown).

BR produced a significantly higher early yield $(P<0.001)$ of 2.8 $\mathrm{Mg} \cdot \mathrm{ha}^{-1}$, while 4 - and 6-week-old SP produced 0.9 and $0.4 \mathrm{Mg} \cdot \mathrm{ha}^{-1}$, respectively. There was no early yield difference between 6-week SP with IBA $\left(1.1 \mathrm{Mg} \cdot \mathrm{ha}^{-1}\right)$ and without IBA $\left(0.9 \mathrm{Mg} \cdot \mathrm{ha}^{-1}\right)$. Four-week-old SP with or without IBA resulted in similar early yield with an average of 0.2 $\mathrm{Mg} \cdot \mathrm{ha}^{-1}$. Higher early yield of BR was related to its higher fruit number, as there was no difference in early $(P=$ $0.149)$ and total $(P=0.156)$ average fruit weight, with an average of 16.7 and $18.9 \mathrm{~g} /$ fruit, respectively. BR resulted in 8.3 fruit/plant, while 6week-old SP with and without IBA averaged 2.8 fruit/plant. Four-weekold SP produced the lowest early fruit number $(P<0.001)$, with an average of 0.5 fruit/plant, with no effect of the IBA treatment. There were no differences in total fruit number $(P=$ $0.611)$ and total yield $(P=0.781)$ among treatments, with an average of 63.1 fruit/plant and $20.9 \mathrm{Mg} \cdot \mathrm{ha}^{-1}$ (data not shown).

2013-14 SEASON. Crown diameter did not differ among transplant types and cultivars at $6(P=0.506)$, $12(P=0.331)$, and $18(P=0.735)$ WAT, with an average of 26,47 , and $59 \mathrm{~cm}$, respectively. For crown number at 6 WAT $(P<0.010)$, there was no difference between SP transplants, with an average of 1.6 crowns/plant. $\mathrm{BR}$ resulted in a lower number of crowns, averaging 1.1 crowns/plant. Similarly, at 12 WAT $(P<0.010)$, SP had a higher crown number per plant than BR, with an average of 2.9 compared with 1.8 , respectively. There was no difference between cultivars at $6(P=0.341)$ and $12(P=$ $0.627)$ WAT, with an average of 1.4 and 2.5 crowns, respectively. At 18 WAT, there were no differences among transplant types $(P=0.469)$ and cultivars $(P=0.950)$, with an average of 2.9 crowns/plant.

$\mathrm{BR}$ produced a higher number of early fruit $(P<0.010)$ per plant with 5.5 fruit, while 4 - and 6-week-old SP produced 0.3 and 0.7 early fruit/ plant, respectively. There was no effect of cultivar $(P=0.305)$ on early fruit number per plant, with an average of 2.2 fruit. Similarly, there was no cultivar $(P=0.144)$ or transplant $(P=0.059)$ effect on early average fruit weight, with averages of 11.8 and $12.4 \mathrm{~g}$, respectively. For total average fruit weight, there were no differences among transplant types $(P=0.522)$, with an average of 17 $\mathrm{g} /$ fruit, but 'Florida Radiance' produced heavier fruit $(18.1 \mathrm{~g})$ than 'Strawberry Festival' (15.9 g) (data not shown).

There was an interaction between transplant type and cultivar for early yield $(P=0.005)$, total fruit number $(P=0.016)$, and total yield $(P=0.004)$. 'Florida Radiance' and 'Strawberry Festival' BR had a higher early yield than SP treatments (Table $1)$. There was no difference between 'Florida Radiance' 4- and 6-week-old SP and 'Strawberry Festival' 4- and 6week-old SP for early yield. 'Florida Radiance' BR had 48\% higher early yield than 'Strawberry Festival' BR (Table 1).

There was no difference in total fruit number between 'Florida Radiance' BR and SP, with an average of 19.6 fruit/plant (Table 1). 'Strawberry Festival' BR resulted in $58 \%$ less fruit than 'Strawberry Festival' SP. There was no difference between 'Strawberry

Table 1. Effect of strawberry transplant type [bare-root, 4- or 6-week-old strawberry plug (SP)] and cultivar interaction on early yield, total fruit number, and total yield at Balm, FL, in the 2013-14 growing season. Early yield was defined as the cumulative marketable fruit weight of all harvests through $15 \mathrm{Dec} .2013$.

\begin{tabular}{|c|c|c|c|}
\hline \multirow[b]{3}{*}{ Cultivar } & \multicolumn{3}{|c|}{ Transplant type } \\
\hline & \multicolumn{3}{|c|}{ Early yield $\left(\mathrm{Mg} \cdot \mathrm{ha}^{-1}\right)^{\mathrm{z}}$} \\
\hline & Bare-root & 4-week-old SP & 6-week-old SP \\
\hline Florida Radiance & $2.2 \mathrm{~A} \mathrm{a}^{\mathrm{y}}$ & $0.9 \mathrm{~B} \mathrm{a}$ & $0.2 \mathrm{~B} \mathrm{a}$ \\
\hline Strawberry Festival & $1.1 \mathrm{~A} \mathrm{~b}$ & $0.1 \mathrm{~B} \mathrm{a}$ & $0.2 \mathrm{~B} \mathrm{a}$ \\
\hline
\end{tabular}

\begin{tabular}{lccc} 
& \multicolumn{3}{c}{ Total fruit (no./plant) } \\
\cline { 2 - 4 } & Bare-root & 4-week-old SP & 6-week-old SP \\
\hline Florida Radiance & $21.7 \mathrm{~A} \mathrm{a}$ & $18.8 \mathrm{~A} \mathrm{a}$ & $18.3 \mathrm{~A} \mathrm{a}$ \\
Strawberry Festival & $8.8 \mathrm{~B} \mathrm{~b}$ & $20.6 \mathrm{~A} \mathrm{a}$ & $21.3 \mathrm{~A} \mathrm{a}$
\end{tabular}

\begin{tabular}{lccc} 
& \multicolumn{3}{c}{ Total yield $\left(\mathbf{M g} \cdot \mathbf{h a}^{-\mathbf{l}}\right)$} \\
\cline { 2 - 4 } & Bare-root & 4-week-old SP & 6-week-old SP \\
\hline Florida Radiance & $7.3 \mathrm{~A} \mathrm{a}$ & $5.7 \mathrm{~A} \mathrm{a}$ & $5.1 \mathrm{~A} \mathrm{a}$ \\
Strawberry Festival & $2.6 \mathrm{~B} \mathrm{~b}$ & $6.3 \mathrm{~A} \mathrm{a}$ & $6.5 \mathrm{~A} \mathrm{a}$ \\
\hline
\end{tabular}

${ }^{\mathrm{z}} 1 \mathrm{Mg} \cdot \mathrm{ha}^{-1}=0.4461$ ton/acre.

${ }^{y}$ Values followed by the different uppercase letters (rows) indicate that the means of the transplant types are significantly different $(P \leq 0.05)$ according to Fisher's protected least significant difference test within cultivars; values followed by the different lowercase letters (columns) indicate that the means of the cultivars are significantly different $(P \leq 0.05)$ according to Fisher's protected least significant difference test within transplant type. 
biomass, with an average of 47.2 $\mathrm{g} /$ plant, while 'Florida127' resulted in $38.4 \mathrm{~g} /$ plant. At $20 \mathrm{WAT}(P=0.484)$, there was no difference among cultivars, with an average of $56.1 \mathrm{~g}$ (data not shown).

For early average fruit weight, total average fruit weight, and total yield, there was no effect of transplant type, averaging $19.6 \mathrm{~g} /$ plant, $24.5 \mathrm{~g} /$ plant, and $27 \mathrm{Mg} \cdot \mathrm{ha}^{-1}$, respectively (Table 2). For early average fruit weight, 'Florida127' resulted in the heavier fruit, while there was no difference between 'Florida Radiance' and 'Strawberry Festival'. Similarly, for total average fruit weight, 'Floridal27' resulted in the higher average fruit weight, followed by 'Florida Radiance'. 'Strawberry Festival' resulted in the lowest average fruit weight (Table $2)$. For total yield, there was no difference between 'Florida Radiance' and 'Floridal27', while 'Strawberry Festival' resulted in the lowest total yield (Table 2).

There was an interaction between transplant type and cultivar for early yield $(P<0.010)$, early fruit number $(P=0.016)$, and total fruit number $(P=0.046)$. For early yield, 'Florida Radiance' and 'Floridal27' BR resulted in a higher early yield than 4-week-old SP. However, 'Strawberry Festival' BR and 4week-old SP had a similar response, with an average of $2 \mathrm{Mg} \cdot \mathrm{ha}^{-1}$ (Table $3)$. For 4-week-old SP, there was no difference among cultivars (Table 3 ).

There was no effect of cultivar on early fruit number for $\mathrm{BR}$, with an average of 8.7 fruit/plant. For 4week-old SP, 'Strawberry Festival' resulted in the highest fruit number, while there was no difference between 'Florida Radiance' and 'Floridal27' (Table 3). For 6-week-old SP, 'Florida Radiance' produced the highest fruit number, while 'Strawberry Festival' produced the lowest (Table 3 ). 'Florida Radiance' and 'Florida127' BR resulted in a higher early fruit number than 4- and 6-week-old SP. However, 'Strawberry Festival' BR and 4-week-old SP had a similar response, with an average of 7.2 fruit/ plant (Table 3).

For total fruit number, there was no cultivar effect for $B R$, with an average of 61.7 fruit/plant. 'Florida Radiance' resulted in a higher fruit number than 'Strawberry Festival' when planted as 4-week-old SP. For 6-week-old SP, 'Florida Radiance' had

Table 2. Effect of strawberry transplant type [bare-root, 4- or 6-week-old strawberry plug (SP)] and cultivar on early and total average fruit weight, and total yield at Balm, FL, in the 2014-15 growing season. Early yield was defined as the cumulative marketable fruit weight of all harvests through 15 Dec. 2014.

\begin{tabular}{lccc}
\hline Treatment & $\begin{array}{c}\text { Avg early fruit } \\
\mathbf{w t}(\mathbf{g} / \text { fruit })^{\mathbf{z}}\end{array}$ & $\begin{array}{c}\text { Avg total fruit } \\
\mathbf{w t}(\mathbf{g} / \mathbf{f r u i t})\end{array}$ & $\begin{array}{c}\text { Total yield } \\
\left(\mathbf{M g} \cdot \mathbf{h a}^{-\mathbf{l}}\right)^{\mathbf{z}}\end{array}$ \\
\hline Cultivars (C) & & & \\
$\quad$ Florida Radiance & $19.2 \mathrm{~b}^{\mathrm{y}}$ & $23.6 \mathrm{~b}$ & $30.1 \mathrm{a}$ \\
Strawberry Festival & $16.1 \mathrm{~b}$ & $20.8 \mathrm{c}$ & $22.4 \mathrm{~b}$ \\
Floridal27 & $23.6 \mathrm{a}$ & $28.9 \mathrm{a}$ & $28.2 \mathrm{a}$ \\
Significance & 0.003 & $<0.0001$ & $<0.0001$ \\
Transplants type (TT) & & & \\
Bare-root & 17.6 & 24.8 & 26.0 \\
4-week-old SP & 20.8 & 25.0 & 28.1 \\
6-week-old SP & 20.5 & 23.8 & 27.4 \\
Significance & 0.210 & 0.126 & 0.358 \\
C $\times$ TT & 0.224 & 0.385 & 0.063 \\
\hline
\end{tabular}

${ }^{\mathrm{z}} 1 \mathrm{~g}=0.0353 \mathrm{oz}, \mathrm{l} \mathrm{Mg} \cdot \mathrm{ha}^{-1}=0.4461$ ton/acre

yValues followed by the different letters indicate that the means of the transplants type are significantly different $(P \leq 0.05)$ according to Fisher's protected least significant difference test.

Table 3. Effect of strawberry transplant type [bare-root, 4- or 6-week-old strawberry plug (SP)] and cultivar interaction on early yield, early fruit number, and total fruit number, at Balm, FL, in the 2014-15 growing season. Early yield was defined as the cumulative marketable fruit weight of all harvests through 15 Dec. 2014.

\begin{tabular}{|c|c|c|c|}
\hline \multirow[b]{3}{*}{ Cultivar } & \multicolumn{3}{|c|}{ Transplant type } \\
\hline & \multicolumn{3}{|c|}{ 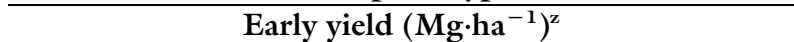 } \\
\hline & Bare-root & 4-week-old SP & 6-week-old SP \\
\hline Florida Radiance & $2.4 \mathrm{~A} \mathrm{ab}^{\mathrm{y}}$ & $1.4 \mathrm{~B} \mathrm{a}$ & $2.2 \mathrm{~A} \mathrm{a}$ \\
\hline Strawberry Festival & $2.1 \mathrm{~A} \mathrm{~b}$ & $2.0 \mathrm{~A} \mathrm{a}$ & $0.6 \mathrm{~B} \mathrm{~b}$ \\
\hline \multirow[t]{3}{*}{ Floridal27 } & $3.1 \mathrm{~A} \mathrm{a}$ & $1.8 \mathrm{~B} \mathrm{a}$ & $1.7 \mathrm{~B} \mathrm{a}$ \\
\hline & \multicolumn{3}{|c|}{ Early fruit (no./plant) } \\
\hline & Bare-root & 4-week-old SP & 6-week-old SP \\
\hline Florida Radiance & $8.6 \mathrm{~A} \mathrm{a}$ & $3.6 \mathrm{~B} \mathrm{~b}$ & $4.9 \mathrm{~B} \mathrm{a}$ \\
\hline Strawberry Festival & $8.0 \mathrm{~A} \mathrm{a}$ & $6.4 \mathrm{~A} \mathrm{a}$ & $1.9 \mathrm{~B} \mathrm{~b}$ \\
\hline \multirow[t]{3}{*}{ Floridal27 } & $9.5 \mathrm{~A} \mathrm{a}$ & $3.6 \mathrm{~B} \mathrm{~b}$ & $3.2 \mathrm{~B} \mathrm{ab}$ \\
\hline & \multicolumn{3}{|c|}{ Total fruit (no./plant) } \\
\hline & Bare-root & 4-week-old SP & 6-week-old SP \\
\hline Florida Radiance & $64.0 \mathrm{~B} \mathrm{a}$ & $72.7 \mathrm{AB}$ a & $79.6 \mathrm{~A} \mathrm{a}$ \\
\hline Strawberry Festival & $63.1 \mathrm{~A} \mathrm{a}$ & $58.6 \mathrm{~A} \mathrm{~b}$ & $58.9 \mathrm{~A} \mathrm{~b}$ \\
\hline Florida127 & $58.0 \mathrm{~A} \mathrm{a}$ & $62.0 \mathrm{~A} \mathrm{ab}$ & $56.4 \mathrm{~A} \mathrm{~b}$ \\
\hline
\end{tabular}

${ }^{\mathrm{z}} 1 \mathrm{Mg} \cdot \mathrm{ha}^{-1}=0.446 \mathrm{l}$ ton/acre.

${ }^{y}$ Values followed by the different uppercase letters (rows) indicate that the means of the transplant types are significantly different $(P \leq 0.05)$ according to Fisher's protected least significant difference test within cultivars; values followed by the different lowercase letters (columns) indicate that the means of the cultivars are significantly different $(P \leq 0.05)$ according to Fisher's protected least significant difference test within transplant type.

the highest fruit number, followed by 'Strawberry Festival' and 'Floridal27', with an average of 57.6 fruit/plant (Table 3).

2015-16 SEASON. Like 201415 , there was no effect of cultivar $(P=0.060)$ or transplant type $(P=$ 0.558 ) on plant biomass, with an average of $10.6 \mathrm{~g} /$ plant at 4 WAT. At $8(P=0.051), 12(P=0.421)$, and 16 $(P=0.796)$ WAT, there was also no effect of cultivar or transplant type on plant biomass, with an average of 15.9 , 18.5 , and $24.8 \mathrm{~g} /$ plant, respectively. At 20 WAT, there was no effect of cultivars $(P=0.263)$ on plant biomass, with an average of $58.7 \mathrm{~g}$. However, 4and 6-week-old SP resulted in 25\% greater plant biomass $(64.1 \mathrm{~g} / \mathrm{plant})$ than BR (47.9 g/plant) (data not shown).

For early fruit number, there was no cultivar effect. However, BR resulted in a higher fruit number than 
Table 4. Effect of strawberry transplant type [bare-root, 4- or 6-week-old strawberry plug (SP)] and cultivar on early and total average fruit weight and fruit number and total yield, at Balm, FL, in the 2015-16 growing season. Early yield was defined as the cumulative marketable fruit weight of all harvests through 15 Dec. 2015.

\begin{tabular}{|c|c|c|c|c|c|}
\hline Treatment & $\begin{array}{c}\text { Early fruit } \\
\text { (no./plant) }\end{array}$ & $\begin{array}{l}\text { Avg early fruit } \\
\text { wt }(\mathrm{g} / \text { plant })^{\mathrm{z}}\end{array}$ & 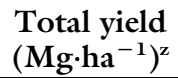 & $\begin{array}{l}\text { Total fruit } \\
\text { (no./plant) }\end{array}$ & $\begin{array}{c}\text { Avg total fruit } \\
\text { wt (g/plant) }\end{array}$ \\
\hline \multicolumn{6}{|l|}{ Cultivar (C) } \\
\hline Florida Radiance & 0.4 & $12.7 \mathrm{~b}^{\mathrm{y}}$ & $11.1 \mathrm{~b}$ & $9.2 \mathrm{~b}$ & $27.3 \mathrm{~b}$ \\
\hline Strawberry Festival & 0.2 & $10.3 \mathrm{~b}$ & $4.4 \mathrm{c}$ & $4.8 \mathrm{c}$ & $20.4 \mathrm{c}$ \\
\hline Floridal27 & 0.5 & $18.8 \mathrm{a}$ & $15.1 \mathrm{a}$ & $10.6 \mathrm{a}$ & $31.8 \mathrm{a}$ \\
\hline Significance & 0.099 & 0.007 & $<0.0001$ & $<0.0001$ & $<0.0001$ \\
\hline 4-week-old SP & $0.2 \mathrm{~b}$ & 11.8 & 10.2 & 20.1 & $27.8 \mathrm{a}$ \\
\hline 6-week-old SP & $0.1 \mathrm{~b}$ & 13.0 & 9.8 & 20.1 & $26.7 \mathrm{ab}$ \\
\hline Significance & $<0.0001$ & 0.087 & 0.576 & 0.105 & 0.016 \\
\hline $\mathrm{C} \times \mathrm{TT}$ & 0.093 & 0.576 & 0.527 & 0.143 & 0.308 \\
\hline
\end{tabular}

${ }^{\mathrm{z}} \mathrm{lg}=0.0353 \mathrm{oz}, \mathrm{l} \mathrm{Mg} \cdot \mathrm{ha}^{-1}=0.4461 \mathrm{ton} /$ acre.

${ }^{y}$ Values followed by the different letters indicate that the means of the transplants type are significantly different $(P \leq 0.05)$ according to Fisher's protected least significant difference test.

4- and 6-week-old SP (Table 4). For early average fruit weight, there was no difference between 'Florida Radiance' and 'Strawberry Festival', with an average of $11.5 \mathrm{~g} /$ fruit, while 'Floridal 27' resulted in 38\% heavier fruit (Table 4). There was no effect of transplant type on early average fruit weight.

For total yield and total fruit number, there was no effect of transplant type, with an average of 10.2 $\mathrm{Mg} \cdot \mathrm{ha}^{-1}$ and 21 fruit/plant, respectively (Table 4). 'Florida 127' resulted in the highest total yield and total fruit number, compared with the rest of the cultivars, while 'Strawberry Festival' resulted in the lowest (Table $4)$. For total average fruit weight, 'Floridal27' resulted in the heaviest fruit, followed by 'Florida Radiance' and 'Strawberry Festival' (Table 4).

There was an interaction between cultivars and transplant type for early yield $(P<0.010)$. For BR, 'Florida Radiance' and 'Strawberry Festival' resulted in a similar yield. 'Floridal27' resulted in the highest early yield compared with the rest of the cultivars (Table 5). For 4- and 6week-old SP, there was no effect of cultivar on early yield. 'Florida Radiance' and 'Strawberry Festival' had similar early yield when planted as BR and 4-week-old SP. In the case of 'Floridal27', BR resulted in the highest early yield compared with 4and 6-week-old SP (Table 5).

\section{Expt. 2: Evaluation of tray sizes}

2013-14 sEAson. At 6 WAT, there was no difference among

Table 5. Effect of strawberry transplant type [bare-root, 4- or 6-week-old strawberry plug (SP)] and cultivar interaction on early yield, at Balm, FL, in the 2015-16 growing season. Early yield was defined as the cumulative marketable fruit weight of all harvests through $15 \mathrm{Dec} .2015$.

\begin{tabular}{lccc}
\hline & \multicolumn{3}{c}{ Transplant type } \\
\cline { 2 - 4 } Cultivar & \multicolumn{3}{c}{ Early yield $\left(\mathbf{M g} \cdot \mathbf{h a}^{-\mathbf{1}}\right)^{\mathrm{z}}$} \\
\cline { 2 - 4 } & Bare-root & 4-week-old SP & 6-week-old SP \\
\hline Florida Radiance & $0.4 \mathrm{~A} \mathrm{~b}^{\mathrm{y}}$ & $0.2 \mathrm{~A} \mathrm{a}$ & $0.0 \mathrm{C} \mathrm{a}$ \\
Strawberry Festival & $0.2 \mathrm{~A} \mathrm{~b}$ & $0.1 \mathrm{~A} \mathrm{a}$ & $0.0 \mathrm{~A} \mathrm{a}$ \\
Floridal27 & $1.2 \mathrm{~A} \mathrm{a}$ & $0.1 \mathrm{~B} \mathrm{a}$ & $0.0 \mathrm{~B} \mathrm{a}$ \\
\hline
\end{tabular}

${ }^{\mathrm{z}} 1 \mathrm{Mg} \cdot \mathrm{ha}^{-1}=0.4461 \mathrm{ton} /$ acre.

${ }^{y}$ Values followed by the different letters indicate that the means of the cultivars are significantly different $(P \leq 0.05)$ according to Fisher's protected least significant difference test.

treatments for crown diameter $(P=$ $0.131)$ and crown number $(P=$ 0.081 ), with an average of $20.6 \mathrm{~mm}$ and 1.5 crowns/plant, respectively. At 12 WAT, there was no treatment effect on crown diameter $(P=0.371)$ and crown number $(P=0.993)$, with an average of $48.7 \mathrm{~mm} /$ plant and 2.6 crowns/plant. At 18 WAT, there was no difference among treatments for crown diameter $(P=0.371)$ and crown number $(P=0.162)$, with an average of $58.6 \mathrm{~mm} /$ plant and 2.5 crowns/plant.

For early yield $(P=0.033), \mathrm{BR}$ produced the highest yield, with 0.98 $\mathrm{Mg} \cdot \mathrm{ha}^{-1}$, while SP treatments resulted in an average of $0.6 \mathrm{Mg} \cdot \mathrm{ha}^{-1}$. Similarly, BR produced 1.7 early fruit/ plant, while SP treatments resulted in an average of 0.1 early fruit/plant.

There was no difference in early $(P=0.602)$ and total $(P=0.272)$ average fruit weight among all treatments, with an average of 14.6 and 17 $\mathrm{g} /$ fruit. Furthermore, there was no difference among treatments for total fruit number $(P=0.258)$ and yield
$(P=0.574)$, with an average of 6.6 fruit/plant and $4.8 \mathrm{Mg} \cdot \mathrm{ha}^{-1}$ (data not shown).

There were no differences between tray size treatments for early and total yield. Therefore, treatments of 30- and 40-cell trays were eliminated from the study for the 2014-15 growing season.

2014-15 SEASON. At 4 and 8 WAT, there was no difference between cultivars for crown diameter and crown number, with averages of $17.6 \mathrm{~mm}(P=0.880)$ and $\mathrm{l}$ crown at 4 WAT, and $27.6 \mathrm{~mm}(P=0.930)$ and 1.4 crowns $(P=0.467)$ at 8 WAT. At weeks 16 and 20, there were no differences between cultivars with averages of $59.8 \mathrm{~mm}(P=0.412)$ and 2.4 crowns $(P=0.148)$ at 16 WAT, and $63.6 \mathrm{~mm}(P=0.956)$ and 4.4 crowns $(P=0.502)$ at 20 WAT.

For transplants types, FL tips in 50- and 72-cell trays, and California tips in 50- and 72-cell trays resulted in similar crown diameter at 4 WAT $(P=$ 0.028 ), with an average of $18.8 \mathrm{~mm}$. $\mathrm{BR}$ resulted in a smaller crown 
diameter, with an average of $13.6 \mathrm{~mm}$. There were no differences among treatments for crown number, with an average of 1 crown/plant. At 8 WAT, there was no difference among treatments for crown diameter $(P=0.569)$ and crown number $(P=0.178)$, with $27.6 \mathrm{~mm}$ and 1.4 crowns. At 16 WAT, there was no difference for crown diameter $(P=0.119)$, with an average of $59.7 \mathrm{~mm}$. However, all SP treatments resulted in a higher crown number $(P=$ 0.005 ) than BR, with an average of 2.5 and 2.1 crowns/plant, respectively. At 20 WAT, CA tips +50 -cell trays produced wider crowns $(P<0.010)$ (73 $\mathrm{mm} /$ plant) than the rest of the treatments $(61.2 \mathrm{~mm} /$ plant $)$. For crown number $(P<0.010)$, BR produced lower numbers of crowns per plant (3.1 crowns/plant) than all SP treatments (4.7 crowns/plant) (data not shown).

At 12 WAT, there was an interaction between cultivars and transplant type for crown diameter and crown number (Table 6). 'Strawberry Festival' Florida tips planted in 50and 72-cell trays and California tips planted in 72-cell trays resulted in the largest crown diameters, while BR control and California tips planted in 50 -cell trays resulted in the smallest crown diameters, with no difference between treatments (Table 6). 'Florida Radiance' BR resulted in the same crown diameter as Florida tips planted in 72-cell trays and California tips planted in 50- and 72-cell trays (Table 6).

For 'Strawberry Festival' crown number, there was no difference among Florida tips planted in 72-cell trays and California tips planted in 50- and 72-cell trays (Table 6). Similarly, 'Florida Radiance' SP treatments resulted in no difference for crown number. 'Strawberry Festival' and 'Florida Radiance' BR resulted in the lowest number of crowns per plant (Table 6).

Early yield was affected by cultivar, where 'Florida Radiance' produced a $56 \%$ higher early yield than 'Strawberry Festival' (Table 7). 'Florida Radiance' also produced $40 \%$ higher early fruit number and $43 \%$

Table 6. Effect of cultivar and transplant type interaction on crown diameter and crown number at 12 weeks after transplant of strawberry plants at Balm, FL, in the 2014-15 growing season.

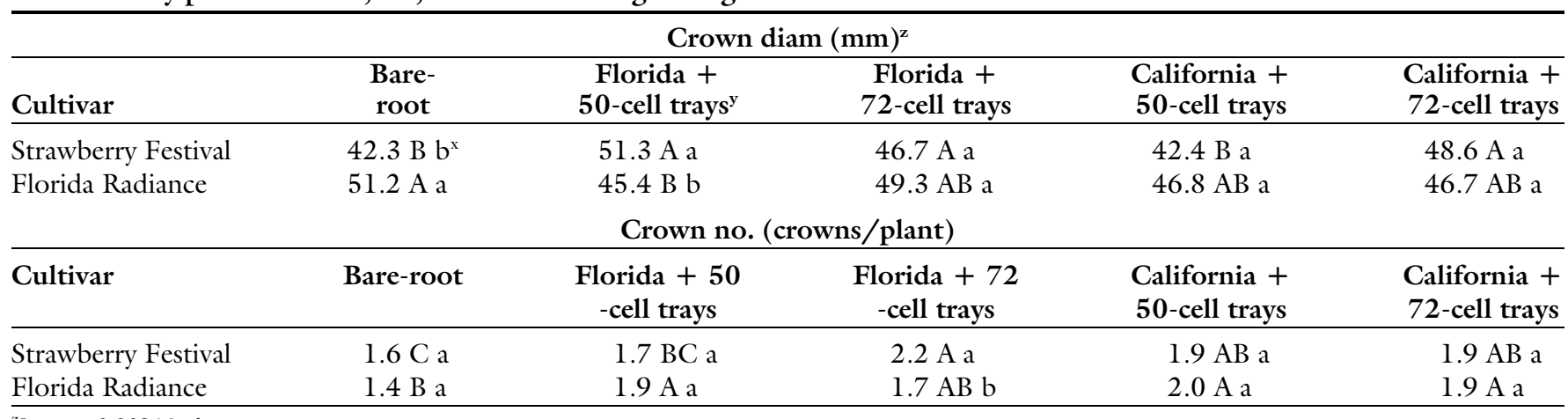

${ }^{\mathrm{z}} \mathrm{l} \mathrm{mm}=0.0394$ inch

${ }^{y}$ Florida +50 -cell trays $=$ runners were grown in Florida in trays with 50 cells before transplanted at the field; California +50 -cell trays $=$ runners were shipped from California to Florida and grown in trays with 50 cells before transplanted at the field; Florida +72 -cell trays = runners were grown in Florida in trays with 72 cells before transplanted at the field; California +72 -cell trays $=$ runners were shipped from California to Florida and grown in trays with 72 cells before transplanted at the field

${ }^{x}$ Values followed by the different uppercase letters (rows) indicate that the means of the treatments are significantly different $(P \leq 0.05)$ according to Fisher's protected least significant difference test within cultivar; values followed by the different lowercase letters (columns) indicate that the means of the treatments are significantly different $(P \leq$ 0.05 ) according to Fisher's protected least significant difference test within tray sizes and tip source combination.

Table 7. Effect of cultivar and transplant type on early and total yield, fruit number, and average fruit weight of strawberry plants, at Balm, FL, in the 2014-15 growing season.

\begin{tabular}{|c|c|c|c|c|c|c|}
\hline Treatment & $\begin{array}{l}\text { Early yield } \\
\left(\mathrm{Mg} \mathrm{ha}^{-1}\right)^{\mathrm{z}}\end{array}$ & $\begin{array}{c}\text { Early fruit } \\
\text { (no./plant) }\end{array}$ & $\begin{array}{l}\text { Avg early fruit } \\
\text { wt }(\mathrm{g} / \text { fruit })^{\mathrm{z}}\end{array}$ & $\begin{array}{l}\text { Total yield } \\
\left({\left.\mathrm{Mg} \cdot \mathrm{ha}^{-1}\right)}^{-1}\right.\end{array}$ & $\begin{array}{l}\text { Total fruit } \\
\text { (no./plant) }\end{array}$ & $\begin{array}{l}\text { Avg total fruit } \\
\text { wt (g/fruit) }\end{array}$ \\
\hline \multicolumn{7}{|l|}{ Cultivar (C) } \\
\hline Strawberry Festival & 0.2 & 0.3 & 10.7 & 27.2 & 29.9 & 20.8 \\
\hline Florida Radiance & 0.5 & 0.5 & 25.0 & 31.4 & 31.5 & 22.7 \\
\hline Significance $\mathrm{e}^{\mathrm{y}}$ & 0.010 & 0.019 & 0.001 & 0.002 & 0.020 & $<0.0001$ \\
\hline \multicolumn{7}{|l|}{ Transplant type (TT) } \\
\hline Bare-root & $0.9 \mathrm{a}$ & $1.3 \mathrm{a}$ & 17.1 & 28.8 & 30.7 & 21.5 \\
\hline Florida +50 -cell trays $\mathrm{x}^{\mathrm{x}}$ & $0.2 \mathrm{~b}$ & $0.2 \mathrm{~b}$ & 24.2 & 32.1 & 33.5 & 21.9 \\
\hline Florida +72 -cell trays & $0.2 \mathrm{~b}$ & $0.2 \mathrm{~b}$ & 14.5 & 25.6 & 27.7 & 21.1 \\
\hline California +50 -cell trays & $0.2 \mathrm{~b}$ & $0.2 \mathrm{~b}$ & 14.5 & 31.5 & 32.4 & 22.2 \\
\hline California +72 -cell trays & $0.2 \mathrm{~b}$ & $0.2 \mathrm{~b}$ & 20.6 & 28.5 & 29.2 & 22.1 \\
\hline Significance & $<0.0001$ & $<0.0001$ & 0.380 & 0.002 & 0.006 & 0.091 \\
\hline $\mathrm{C} \times \mathrm{TT}$ & 0.728 & 0.569 & 0.226 & 0.007 & 0.024 & 0.005 \\
\hline
\end{tabular}

${ }^{\mathrm{z}} 1 \mathrm{~g}=0.0353 \mathrm{oz}, \mathrm{l} \mathrm{Mg} \cdot \mathrm{ha}^{-1}=0.4461 \mathrm{ton} /$ acre.

'Values followed by the different letters indicate that the means of the transplant type are significantly different $(P \leq 0.05)$ according to Fisher's protected least significant difference test.

${ }^{\mathrm{x}}$ Florida +50 -cell trays $=$ runners were grown in Florida in trays with 50 cells before transplanted at the field; California +50 -cell trays $=$ runners were shipped from California to Florida and grown in trays with 50 cells before transplanted at the field; Florida +72 -cell trays $=$ runners were grown in Florida in trays with 72 cells before transplanted at the field; California +72 -cell trays $=$ runners were shipped from California to Florida and grown in trays with 72 cells before transplanted at the field 
heavier fruit than 'Strawberry Festival' (Table 7 ).

Transplant type affected early yield and early fruit number. BR resulted in the highest early yield and early fruit number compared with the rest of the treatments. There was no difference among the SP treatments for early yield and early fruit number. Transplant type did not affect early average fruit weight (Table 7 ). There was an interaction between cultivars and transplant type for total yield, total fruit number, and total average fruit weight.

'Strawberry Festival' produced the same total yield when planted as $\mathrm{BR}$, and Florida and California tips in 50-cell trays (Table 8). In the case of 'Florida Radiance', Florida and California tips planted in 50-cell trays and California tips planted in 72-cell trays resulted in the highest total yield, compared with Florida tips planted in 72-cell trays and BR (Table 8). Overall, 'Florida Radiance' produced higher total yield than 'Strawberry Festival', except for BR transplants.

In terms of total fruit number, $\mathrm{BR}$ and tips planted in 50-cell trays produced a higher fruit number than 72-cell for 'Strawberry Festival' (Table 8). For 'Florida Radiance', Florida tips planted in 50-cell trays and California tips planted in 50- and 72-cell trays resulted in the highest fruit number (Table 8). Florida tips of 'Florida Radiance' planted in 72 -cell trays and Florida tips of 'Strawberry Festival' planted in 50-cell trays had the lowest total average fruit weight, compared with the rest of the treatments (Table 8).

\section{Discussion}

After four seasons of data collection, BR transplants produced higher early yield than SP, while there was no difference between SP and BR transplants for total yield. Furthermore, 4 weeks of growth before field transplanting and 50cell trays were adequate for Floridaproduced SP.

BR consistently had a higher early yield than SP, ranging from $36 \%$ to $91 \%$ between 2012 and 2016. This was likely due to the nursery conditions to which BR were exposed. The transition from vegetative to a floral apex in strawberry requires an induction process that is influenced by the environment (photoperiod, air temperature, carbon dioxide concentration) and plant development. Florida strawberry production is based on short-day cultivars such as those used in this study, which generally initiate flowering under photoperiods $\leq \mathrm{l} 4 \mathrm{~h}$ and air temperatures lower than $60{ }^{\circ} \mathrm{F}$ (Darnell et al., 2003; Verheul et al., 2007). BR are usually grown in northern latitudes and/or at high elevations that are much cooler than in Florida. The accumulated chilling hours to which the BR were subjected before planting are assumed to have promoted flower bud initiation. This argument was supported by the higher fruit number of the $\mathrm{BR}$, originating from a higher production of flowers early in the season, with no change in average fruit weight.

Furthermore, FL-produced SP grew at an average air temperature of $26.5^{\circ} \mathrm{C}$ in September, with an average maximum air temperature of $32{ }^{\circ} \mathrm{C}$ (as shown in Fig. 1). These temperatures lead to a delay in flower bud initiation, as long days and air temperatures above $28{ }^{\circ} \mathrm{C}$ generally reduce flower bud initiation in short-day cultivars (Hancock, 1999; Rantanen et al., 2015). High air temperatures between August and September could have also contributed to the Florida-produced SP excessive vegetative growth. In short-day cultivars, vegetative growth is favored by long days and high air temperature, while flowering inhibits runner production (Perrotte et al., 2016). Florida-produced SP had a higher accumulation of dry biomass, likely related to the active formation of runners and crowns, while BR had lower dry biomass accumulation probably due to pre-season induction and continuous flowering.

Although BR transplants generally had higher early yields compared with the Florida-produced SP, this did not occur in 2015, as 'Florida Radiance' and 'Strawberry Festival' BR had similar early yields to 4- and

Table 8. Effect of cultivar and transplant type interaction on total yield, fruit number, and average fruit weight of strawberry plants at Balm, FL, in the 2014-15 growing season.

\begin{tabular}{|c|c|c|c|c|c|}
\hline \multirow[b]{2}{*}{ Cultivar } & \multicolumn{5}{|c|}{ Total yield $\left(\mathrm{Mg} \cdot \mathrm{ha}^{-1}\right)^{\mathrm{z}}$} \\
\hline & Bare-root & Florida +50 -celly & Florida +72 -cell & California +50 -cell & California +72 -cell \\
\hline \multirow{2}{*}{$\begin{array}{l}\text { Strawberry Festival } \\
\text { Florida Radiance }\end{array}$} & $29.8 \mathrm{~A} \mathrm{a}^{\mathrm{x}}$ & $28.3 \mathrm{AB} \mathrm{b}$ & $24.9 \mathrm{BC} \mathrm{b}$ & $29.1 \mathrm{AB} b$ & $23.7 \mathrm{C} \mathrm{b}$ \\
\hline & \multicolumn{5}{|c|}{ Total fruit (no./plant) } \\
\hline Cultivar & Bare-root & Florida +50 -cell & Florida +72 -cell & California +50 -cell & California +72 -cell \\
\hline & \multicolumn{5}{|c|}{ Avg total fruit wt (g/fruit) $)^{z}$} \\
\hline Cultivar & Bare-root & Florida +50 -cell & Florida +72 -cell & California +50 -cell & California +72 -cell \\
\hline Strawberry Festival & $21.0 \mathrm{AB}$ a & $20.0 \mathrm{~B} \mathrm{~b}$ & $20.9 \mathrm{AB}$ a & $20.7 \mathrm{AB}$ a & $21.3 \mathrm{Ab}$ \\
\hline Florida Radiance & $21.9 \mathrm{BC} \mathrm{a}$ & $23.7 \mathrm{~A} \mathrm{a}$ & $21.4 \mathrm{C} \mathrm{a}$ & $23.7 \mathrm{~A} \mathrm{a}$ & $23.0 \mathrm{AB}$ a \\
\hline
\end{tabular}

${ }^{\mathrm{z}} \mathrm{lg}=0.0353 \mathrm{oz}, \mathrm{l} \mathrm{Mg} \cdot \mathrm{ha}^{-1}=0.4461 \mathrm{ton} / \mathrm{acre}$.

${ }^{y}$ Florida +50 -cell trays $=$ runners were grown in Florida in trays with 50 cells before transplanted at the field; California +50 -cell trays $=$ runners were shipped from California to Florida and grown in trays with 50 cell before transplanted at the field; Florida +72 -cell trays $=$ runners were grown in Florida in trays with 72 cells before transplanted at the field; California +72 -cell trays $=$ runners were shipped from California to Florida and grown in trays with 72 cells before transplanted at the field.

${ }^{x}$ Values followed by the different uppercase letters (rows) indicate that the means of the treatments are significantly different $(P \leq 0.05)$ according to Fisher's protected least significant difference test within cultivar; values followed by the different lowercase letters (columns) indicate that the means of the treatments are significantly different $(P \leq$ 0.05 ) according to Fisher's protected least significant difference test within tray sizes and tip source combination. 


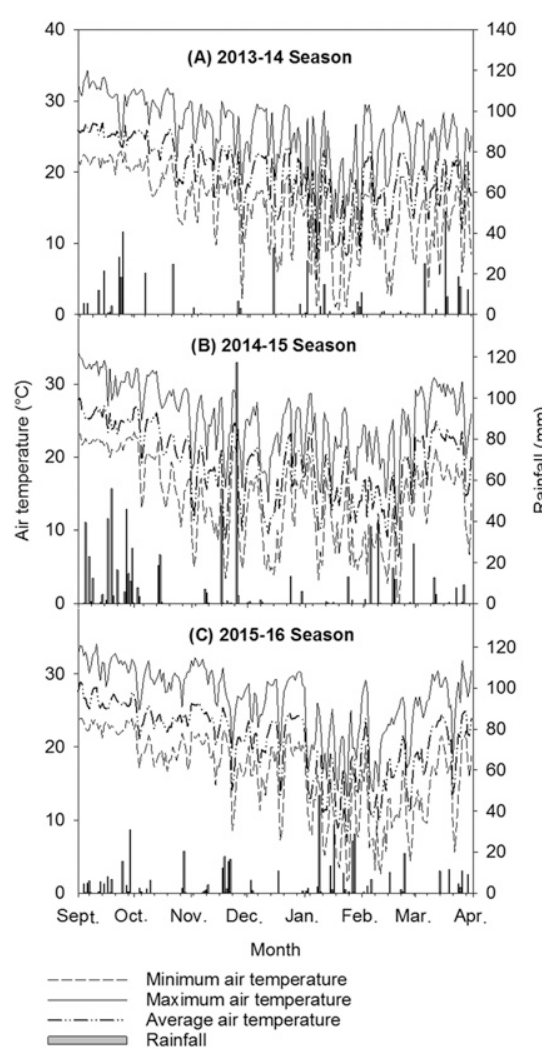

Fig. 1. Minimum, average, and maximum air temperature and rainfall at the Balm, FL experimental site in (A) 2013-14, (B) 2014-15, and (C) 2015-16 strawberry growing seasons; $\left(1.8 \times{ }^{\circ} \mathrm{C}\right)+32={ }^{\circ} \mathrm{F}, 1 \mathrm{~mm}=$ 0.0394 inch.

6-week-old SP. These results may be attributed to differences in air temperature between seasons, especially in November and December. In 2015 , average air temperature in $\mathrm{No}^{-}$ vember and December were 4.8 and $5.9{ }^{\circ} \mathrm{C}$ higher than the 20 -year average for those months, respectively (FAWN, 2019). These temperatures could have inhibited floral bud development in all treatments, but most noticeably decreasing 'Florida Radiance' BR's early yield from $2.4 \mathrm{Mg} \cdot \mathrm{ha}^{-1}$ in 2014-15 to $0.4 \mathrm{Mg} \cdot \mathrm{ha}^{-1}$ in 2015-16.

In the case of 'Strawberry Festival', there was no difference between BR and 4-week-old SP in 2014-15 and 2015-16, while in 2013-14 BR resulted in a higher early yield than SP. This is probably related to the induction cycle requirement of the cultivar, as in 2013 BR received 376 $\mathrm{h}$ of conditioning, while in 2014-15 and 2015-16 plants received 238 and $264 \mathrm{~h}$, respectively. Therefore, 'Strawberry Festival' BR probably did not accumulate enough chilling hours and subsequent early flowers in 2014-15 and 2015-16 to surpass the 4-weekold SP. 'Strawberry Festival' appears to have a higher optimum number of chill hours to maximize yield compared with the newer cultivars.

Another important finding was the higher SP total yield response compared with BR. A higher number of crowns, triggered by environmental conditions promoting vegetative growth, could explain the increase in production later in the season, as flower buds are originated at the crown site.

A third important finding was that Florida-produced SP can be grown for 4 weeks before field transplanting. There was no difference between 4- and 6-week-old SP for total yield across the 4 years of study, while results were inconsistent for early yield. However, an economic analysis is necessary to identify the cost of Florida-produced SP. Nevertheless, the added cost of an extra 2 weeks of maintenance for the 6-weekold SP suggests that 4 -week-old SP is the most adequate time in nursery should this type of transplant be pursued in the future.

In terms of tray size, small cell sizes reduced the total yield response of 'Strawberry Festival' SP. When SP were transplanted in the field, the smaller cell sizes of the 72cell trays might have restricted the development of the root system, translating to limited water and nutrient uptake and therefore decreased vegetative growth. A larger root-mass is more likely to have better contact with the soil surface, increasing water uptake and establishment (Grossnickle, 2004). Adequate conditions for root growth were provided by the 50 -cell trays. Furthermore, selecting tips for SP directly from California did not influence strawberry yield, probably due to insufficient conditioning at such an early stage of the plant.

During the nursery stage, plant mortality rates between $20 \%$ and $50 \%$ of the tray were observed, especially for the 6-week-old SP and 72-cell trays. Also, BR showed a steadier yield trend than SP, which could allow for higher profits based on the price trends of Florida.

The findings of the present study revealed the response of commonly used cultivars in Florida when subjected to local SP production. Future research should focus on developing low-cost techniques for flower induction, as this is the clear limiting aspect of this transplant type. Nevertheless, SP have the potential for significant water savings during plant establishment. In all seasons, SP were established with $80 \%$ less water than the BR. Thus, SP could potentially result in water savings of almost 820,800 gal/acre per season.

In conclusion, FL-produced SP grown for 4 weeks during the nursery stage and planted in 50-cell trays may be an alternative to BR for total yield, if their acquisition cost is economically competitive and floral induction can be improved. At present, BR still provide a steadier production pattern and higher early yield than Florida-produced SP.

\section{Literature cited}

Bish, E.B., D.J. Cantliffe, and C.K. Chandler. 2003. Plantlet size affects growth and development of strawberry plug transplants. Proc. Florida Soc. Hort. Sci. 116:105-107.

Bish, E.B., D.J. Cantliffe, G.J. Hochmuth, and C.K. Chandler. 1997. Development of containerized strawberry transplants for Florida's winter production system. Acta Hort. 439:469-474.

Cantliffe, D.J., A.V. Paranjpe, P.J. Stoffella, E.M. Lamb, and C.A. Powell. 2007. Influence of soilless media, growing containers, and plug transplants on vegetative growth and fruit yield of 'Sweet Charlie' strawberry grown under protected culture. Proc. Florida Soc. Hort. Sci. 120:142-150.

Cluever, J.D., H.A. Smith, C.A. Nagle, J.E. Funderburk, and G. Frantz. 2016. Effect of insecticide rotations on density and species composition of thrips (Thysanoptera) in Florida strawberry (Rosales: Rosaceae). Fla. Entomol. 99:203-209.

Crawford, T.D., D.G. Himelrick, J.L. Sibley, and J.A. Pitts. 2000. Effect of runner plantlet size on performance of strawberry plug plants. Small Fruit Rev. 1(1):15-21.

Darnell, L.D., D.J. Cantliffe, D.S. Kirschbaum, and C.K. Chandler. 2003. The physiology of flowering in strawberry. Hort. Rev. 28:325-349.

Durner, E.F. 2015. Photoperiod and temperature conditioning of 'Sweet Charlie' strawberry (Fragaria $\times$ ananassa Duch.) plugs enhances off-season production. Scientia Hort. 201:184-189.

Durner, E.F., E.B. Poling, and J.L. Maas. 2002. Recent advances in strawberry plug transplant technology. HortTechnology 12:545-550. 
Florida Automatic Weather Network. 2019. Report Generator-Balm, FL. 4 Feb. 2019. $<$ https://fawn.ifas.ufl.edu/data/reports/>.

Forcelini, B.B., F.P. Gonçalves, and N.A. Peres. 2017. Effect of inoculum concentration and interrupted wetness duration on the development of anthranose fruit rot of strawberry. Plant Dis. 101:372-377.

Grossnickle, S.C. 2004. Importance of root growth in overcoming planting stress. New For. 30:273-294.

Hancock, J.F. 1999. Strawberries. CABI, Wallingford, U.K.

Hennion, B., J. Schupp, and J. Longuesserre. 1997. 'Fraisimotte': A strawberry plug plant developed by CIREF in France. Acta Hort. 439:469-474.

Hochmuth, G., D. Cantliffe, C. Chandler, C. Stanley, E. Bish, E. Waldo, D. Legard, and J. Duval. 2006a. Containerized strawberry transplants reduce establishment period, water use and enhance early growth and flowering compared with bare-root plants. HortTechnology 16:46-54.

Hochmuth, G., D. Cantliffe, C. Chandler, C. Stanley, E. Bish, E. Waldo, D. Legard, and J. Duval. 2006b. Fruiting responses economics of containerized and bare-root strawberry transplants established with different irrigation methods. HortTechnology 16:205-210.

Hokanson, S.C., F. Takeda, J.M. Enns, and B.L. Black. 2004. Influence of plant storage duration on strawberry runner tip viability and filed performance. HortScience 39:1596-1600.
Janisch, D.I., J.L. Andriolo, V. Toso, K.G. Ferreira dos Santos, and J. Maronez de Souza. 2012. Nitrogen for growth of stock plants and production of strawberry runner tips. Bragantia 71:394-399.

Lassen Canyon Nursery, Inc. 2016. Macdoel ranch cumulative chilling hours. 13 Oct. 2016. <https://www.lassencanyonnursery. com/cumulative-chilling-hours-weatherconditions $/>$.

Lieten, P. 2012. Advances in strawberry substrate culture during the last twenty years in the Netherlands and Belgium. Intl. J. Fruit Sci. 13:84-90.

Perrotte, J., A. Gaston, A. Potier, A. Petit, C. Rothan, and B. Denoyes. 2016. Narrowing down the single homoeologous FaPFRU locus controlling flowering in cultivated octoploid strawberry using a selective mapping strategy. Plant Biotechnol. J. 14:2176-2189.

Rantanen, M., T. Kurokura, P. Jiang, K. Mouhu, and T. Hytönen. 2015. Strawberry homologue of TERMINAL FLOWERI integrates photoperiod and temperature signals to inhibit flowering. Plant J. 82:163173.

Santos, B.M., C.D. Stanley, A.J. Whidden, T.P. Salame-Donoso, V.M. Whitaker, I.M. Hernandez-Ochoa, P. Huang, and E.A. Torres-Quezada. 2012. Improved sustainability through novel water management strategies for strawberry transplant establishment in Florida, United States. Agronomy 2:312-320.

Simonne, E.H. and M.D. Dukes. 2009 Principles and practices of irrigation management for vegetables, p. 17-23. In: S.M.
Olson and E.H. Simonne (eds.). Vegetable production handbook for Florida 20092010. Vance Publ., Lenexa, KS.

Southwest Florida Water Management District. 2000. Use of containerized strawberry transplants for water conservation and increased early production under a winter annual production system in Florida. Southwest Florida Water Management District, Brooksville, FL.

Takeda, F., D.M. Glenn, A. Callahan, J. Slovin, and G.W. Stutte. 2010. Delaying flowering in short-day strawberry transplants with photo selective nets. Intl. J. Fruit Sci. 10:134-142.

Treder, W., A. Tryngiel-Gać, and K. Klamkowski. 2015. Development of greenhouse soilless system for production of strawberry potted plantlets. HortScience 42:29-36.

U.S. Department of Agriculture. 2019. Web soil survey. 24 Nov. 2019. <https:// websoilsurvey.sc.egov.usda.gov/App/ HomePage.htm>.

Verheul, M.J., A. Sonsteby, and S.O. Grimstad. 2007. Influences of day and night temperatures on flowering of Fragaria $\times$ ananassa Duch., cvs. Korona and Elsanta, at different photoperiods. Scientia Hort. 112:200-206.

Wan, C., L. Mi, B. Chen, J. Li, H. Huo, J. $\mathrm{Xu}$, and $\mathrm{X}$. Chen. 2018. Effects of nitrogen during nursery stage on flower bud differentiation and early harvest after transplanting in strawberry. Braz. J. Bot. 41:1-10. 